\title{
ÉCFRASE: DE RECURSO RETÓRICO NA ANTIGUIDADE A FENÔMENO MIDIÁTICO NA CONTEMPORANEIDADE*
}

Miriam de Paiva Vieira* *

Resumo: A grande maioria das propostas de categorizações para o estudo de intermidialidade utilizam a écfrase como um tipo relevante de fenômeno que atravessa fronteiras entre diferentes mídias. Assim, o objetivo deste ensaio é traçar uma revisão teórica do conceito de écfrase para demostrar como esse recurso retórico utilizado na Antiguidade foi incorporado pelos estudos da intermidialidade na contemporaneidade como um fenômeno midiático.

Palavras-chave: Écfrase. Intermidialidade. Fenômeno midiático.

C omo a écfrase, recurso retórico difundido entre os gregos e romanos, pode ilustrar modelos delineados na atualidade para o estudo da comunicação que atravessa as fronteiras entre as mídias? O objetivo do presente ensaio é traçar uma revisão teórica do conceito de écfrase e demonstrar como esse recurso retórico utilizado na Antiguidade foi incorporado pelos estudos da intermidialidade na contemporaneidade como um fenômeno midiático.

A écfrase é definida por manuais retóricos gregos (os Progymnasmata) como um tropo (figura de pensamento). Segundo Hélio Teão (apud CHINN, 2007, p. 267), esse "discurso descritivo" é uma "composição que expõe em detalhe e apresenta diante dos olhos de maneira evidente o objeto mostrado" (TEÃO apud RODOLPHO, 2012, p. 163). Etimologicamente, o termo vem de uma combinação do verbo grego phrazein/phrazein (contar, declarar, pronunciar, mostrar) com o prefixo ek- (fora ou completamente, integralmente), ou seja, a ekphrasis deve revelar ou relatar algo em seus mínimos detalhes. Em latim, é traduzido como descriptio. O termo foi retomado no século XIX para definir um tipo específico de

\footnotetext{
* Esse ensaio é uma compilação da primeira parte do primeiro capítulo da minha tese de doutorado intitulada Dimensões da écfrase: a presença da pintura e da arquitetura em romances de artista (2016).

** Universidade Federal de Minas Gerais (UFMG) - Belo Horizonte - MG - Brasil. E-mail: miriamvieira@gmail.com
} 
descrição literária, como consta no Dicionário clássico Oxford, que define écfrase como "uma extensa e detalhada descrição literária de qualquer objeto, real ou imaginário" (THE OXFORD CLASSICAL DICTIONARY, 1996, p. 515). Ou seja, de acordo com a noção da Antiguidade, a écfrase é um tipo de recurso retórico, mas, de acordo com a definição proposta no século XIX, é um tipo de recurso literário. Ambos os casos tratam de descrições, mas a maior diferença entre as definições reside no fato de que a écfrase clássica era uma tradição oral que deveria ser fixada na mente da audiência de maneira a perpetuar a memória e a história, enquanto, uma vez consolidada a reprodutibilidade técnica no século XIX, as palavras não mais se dissolvem no ar, consequentemente, a função da écfrase passa a ser de cunho literário.

No século XXI, Werner Wolf e Bernhart (2007, p. 49) sugerem que o termo "écfrase" seja adotado para designar descrições literárias de obras de arte visuais, já que o objetivo dessa variação de referência intermidiática é desencadear uma percepção imaginária das obras ou mídias em questão. James Heffernan (2015, p. 48), entre outros, estabelece a écfrase como um gênero literário. Portanto, mesmo que na atualidade o termo seja ainda bastante utilizado em sua forma restritiva, nos moldes do século XIX, ou seja, para investigar descrições verbais (em forma de poesia) de signos não verbais (em forma de pintura), estudos contemporâneos propõem o resgate de elementos da tradição retórica clássica a fim de abranger outros tipos de manifestação artística, como escultura, instalação e arquitetura, nos estudos sobre outros gêneros literários, tais como romances e contos, e também o cinema.

Como toda écfrase é tida, em geral, como descrição, mas nem toda descrição é uma écfrase, o conceito de descrição será apresentado para esclarecer as sutilezas de tal distinção. Sobre os estudos da descrição em romances do século XIX, Philippe Hamon (1976, p. 57) alega que o "leitor reconhece e identifica sem hesitar uma descrição: ela é um 'corte' na narrativa, a narrativa 'interrompe-se", e explica ainda que

[...] a descrição será, pois, o lugar onde a narrativa se interrompe, onde se suspende, mas igualmente, o espaço indispensável onde se "põe em conserva", onde se "armazena" a informação, onde se condensa e se redobra, onde personagens e cenário, por uma espécie de "ginástica" semântica [...], entram em redundância; o cenário confirma, precisa ou revela a personagem como feixe de traços significativos simultâneos, ou, então, introduz um anúncio (ou um engano) para o desenrolar da ação. [...] Pode-se dizer, então, que, por um lado, desempenha o papel de "organizador" da narrativa, $e$, por outro lado - pela redundância que nela introduz -, o papel de sua memória (HAMON, 1976, p. 73-74).

Já Wolf e Bernhart (2007) argumentam que a descrição, independentemente de sua data de elaboração, é um fenômeno transmidiático em que a mídia tem um papel relevante. Diferentes mídias apresentam diferentes potenciais descritivos de acordo com o enquadramento da descrição em questão. A verbalização favorece a representação de objetos espaciais estáticos e a descrição de processos (WOLF; BERNHART, 2007, p. 78). Devido à natureza da mídia verbal, descrições em obras literárias possuem menos potencial descritivo do que pinturas. Enquanto uma representação pictural favorece a simultaneidade, uma representação verbal é temporal e dinâmica, ou seja, desdobra-se em uma sequência. Uma das vantagens da mídia verbal é sua flexibilidade referencial: é muito difícil 
encontrar um fenômeno concebivel ou mesmo objetos concretos que não possam ser descritos por meio de palavras (WOLF; BERNHART, 2007, p. 49).

Mieke Bal (2006, p. 96) historia a maneira como a teoria e a crítica tratavam com descaso a descrição através de um discurso defensivo e, por vezes, até mesmo preconceituoso até a segunda metade do século XX. Para Bal (1991, p. 109), as definições mais corriqueiras do termo "descrição" utilizadas no século XIX, elencadas no artigo de Gérard Genette "Frontières du récit" (1969), são problemáticas, tanto pela falta de características próprias quanto por serem baseadas em uma distinção entre o descritivo e a narrativa "pura". Ela afirma ainda que a teoria narrativa do século XX na Europa situa a descrição nas "fronteiras da narração", como um "suplemento derridiano". No entanto, com base em investigação desenvolvida nos anos 1980, a autora argumenta que, mesmo quando parece ser somente um acréscimo, a descrição não é um elemento alheio, pois continua sendo indispensável à narrativa. No caso de romances, as passagens descritivas têm o mesmo peso que a representação das ações (BAL, 2006, p. 9697). Ou seja, ainda que os estudos da narração tenham deixado, muitas vezes, o estudo da descrição em segundo plano, não se pode ignorá-lo.

Apesar de já terem sido consideradas meros ornamentos decorativos, passagens descritivas não são supérfluas, uma vez que preenchem uma série de funções na narrativa. Para Genette (1969, p. 57), não existe narração sem descrição, e a descrição pode até mesmo servir à narrativa, como no caso de romances escritos no século XIX. De acordo com Wolf e Bernhart (2007), a função mais óbvia da descrição é o enriquecimento do apelo perceptivo e, consequentemente, o aumento da natureza persuasiva e experimental da narrativa. Para ele, descrições verbais conseguem alcançar o domínio de todos os cinco sentidos (WOLF; BERNHART, 2007, p. 55-56). Assim, devido a sua evidente natureza transmidiática, além de se configurar como um procedimento atemporal presente em mídias tanto verbais quanto não verbais, a descrição pode ser percebida como uma forma de estimular a imaginação do leitor de modo a promover sua interação com a obra literária.

Em revisão literária dos estudos sobre descrição, três questionamentos aparecem de maneira recorrente. O primeiro faz menção à antiga prática de transformar a descrição em uma longa lista de itens sucessivos e prorrogáveis; o segundo, de ordem estrutural, diz respeito à quantidade de detalhes descritivos; e um terceiro se refere à identificação de enquadramento, isto é, onde e como se dá o início e o fim de uma descrição. Para Evelyn Cobley (1986), uma vez que o enquadramento de trechos descritivos é identificado por seus respectivos marcadores, o início das descrições não costuma apresentar grandes problemas. Já a finalização costuma apresentar problemas de organização, marcação e motivação. Diferentemente da narração, em que o final é o resultado lógico de um desenvolvimento precedente, a finalização de descrições é mais ou menos arbitrária (COBLEY, 1986), pois pode acontecer a qualquer momento, cabendo ao descritor decidir, ainda que isso seja dificil, o que deve acontecer aqui e não ali.

\footnotetext{
De acordo com Jacques Derrida (1976, p. 144-145), o suplemento é como uma entidade anexada à obra original, que sempre acrescenta algo novo, indefinidamente, sem apagar os vestígios da fonte e/ou dos suplementos anteriores. Diferentemente do conceito de palimpsesto proposto por Gérard Genette (1997, contracapa - tradução de Sônia Queiroz), em que um texto literário é como um "pergaminho cuja primeira inscrição foi raspada para se traçar a outra, que não a esconde de fato, de modo que se possa lê-la por transparência, o antigo sob o novo", o suplemento adiciona para substituir, mas, mesmo que aconteça uma substituição, a fonte nunca irá desaparecer. Para Derrida (1976, p. 163), o jogo das substituições preenche e marca determinadas lacunas. O suplemento é um tipo de ponto cego no texto, que abre e limita a visibilidade do não visto. O autor salienta o papel fundamental exercido pelo leitor nesse processo (DERRIDA, 1976, p. 157-158).
} 
Mieke Bal (1991, p. 115-117) afirma que o estudo das descrições não pode ser realizado por meio de fragmentos ou recortes isolados do texto. Acrescenta que "o efeito de uma descrição não se restringe à passagem descritiva em si [...] todo detalhe deve ser relacionado com o todo; nada é supérfluo; nada é irrelevante; nada é insignificante" (BAL, 1991, p. 132). Além de uma análise dos marcadores da descrição, portanto, é importante considerar criticamente o que antecede e o que sucede as passagens descritivas na narrativa para um melhor entendimento e compreensão, não somente da motivação e da focalização em questão, mas também da investigação daquele produto cultural como um todo.

Bal (2006, p. 97) também argumenta que a descrição pode diminuir o ritmo do fluxo do tempo da narrativa, mas não chega a interrompê-lo. Wolf e Bernhart (2007) afirmam que passagens descritivas nunca acontecem aleatoriamente no texto, o que remete à função "arquitetônica" das descrições, visto que podem ser utilizadas para estruturar uma narrativa quando organizadas de forma a iniciar importantes cenas em tom de show (mimese) em vez de tell (diegese) ${ }^{2}$. Informar ao leitor os detalhes do meio em que a personagem vive equivale à descrição dessa mesma personagem. As descrições podem ter o propósito de contribuir para a explicação de elementos da história e revelar a personalidade de personas fictícias. Sem intenção de restringir a função da descrição à teoria da recepção, o crítico afirma que descrições "pintam" o contexto, criando um ambiente favorável a um suspense que desencadeia a ação e que geralmente aprimora a ilusão estética ou a imersão do leitor na trama (WOLF; BERNHART, 2007, p. 56-58). Wolf e Bernhart (2007) ainda sugerem que um dos aspectos mais importantes do estudo da descrição no contexto da intermidialidade é a correspondência estabelecida, por exemplo, entre a paisagem e os estados psicológicos, princípio básico da ficção desde o Romantismo, do qual se apoderam hoje outras mídias, especialmente o cinema.

Em poucas palavras, seguindo a argumentação de Mieke Bal (2006, p. 97) de que a écfrase é tanto narrativa quanto descritiva, as investigações sobre esse recurso literário foram norteadas pelos seguintes parâmetros fundamentados nos estudos da descrição: a crença em sua relevância na narrativa, uma vez que as passagens descritivas não podem ser ignoradas dentro de um produto cultural; o envolvimento do leitor durante o processo de transposição midiática; as características inerentes às mídias envolvidas; o estudo do produto cultural como um todo, e não somente de fragmentos de passagens descritivas, considerando sempre o que vem antes e depois do enquadramento de cada trecho, assim como seus respectivos marcadores.

A seguir, serão buscadas nas origens clássicas do conceito a argumentação que fundamenta a definição contemporânea de écfrase: um modo de representação, e não simplesmente uma variável da descrição.

Ruth Webb (2007, p. 15) explica que, apesar de algumas definições de écfrase sugerirem uma investigação arqueológica da gênese do texto ecfrástico, a definição retórica enfoca a "problemática de audiência e de recepção", uma vez que a écfrase "faz o observador 'ver' com seu olho mental". É uma "resposta vi-

2 Gérard Genette (1995, p. 28) explica que "a categoria do aspecto recobria essencialmente as questões do ponto de vista narrativo, que a crítica americana de tradição jamesiana geralmente trata em termos de oposição entre showing (representação - no vocabulário de Todorov) e telling (narração), ressurgências das categorias platônicas de mimesis (imitação perfeita) e de diegesis (narrativa pura), os diversos tipos de representação do discurso de personagem, os modos de presença implícita ou explícita do narrador e do leitor na narrativa". 
sualmente imaginativa às palavras" (WEBB, 2007, p. 16) que, através da interação entre palavra e imagem, dá acesso a representações de uma determinada experiência. Esse tipo abrangente de visualidade faz com que o receptor sinta a presença da cena descrita, seja um evento, seja uma paisagem, seja ainda um edificio. Logo, a relação entre a écfrase e sua fonte inspiradora deve ser tratada por seu impacto psicológico, e não simplesmente como referência. Assim, em vez de insistir na tarefa impossivel de recriar um objeto material por meio da mídia imaterial da palavra, Webb (2007, p. 14) sugere que, ao criar a ilusão de "ver", a écfrase antiga não busca imitar um determinado objeto, e sim o ato de percepção desse objeto. Apesar de sutil, tal distinção é relevante, pois um dos principais objetivos do exercício retórico da écfrase é exatamente criar uma impressão visual na mente do ouvinte.

De acordo com Heidrun Führer e Bernadette Banaszkiewicz (2014, p. 54-58), do ponto de vista retórico, a écfrase deve extrapolar a descrição de objetos per se, a fim de evocar também um certo significado social, ideias e, principalmente, seu impacto emocional. Assim, a écfrase abrange, como Webb preconiza, a atividade criativa da imaginação tanto pelo enunciador quanto pelo receptor, suscitando a presença fictícia de um objeto ou cena ausente. Portanto, além de a écfrase ser "a arte de provocar uma visão" (FÜHRER; BANASZKIEWICZ, 2014, p. 50), é também um recurso "complexo de visão retórica que se refere à capacidade da linguagem de evocar imagens mentais" (FÜHRER; BANASZKIEWICZ, 2014 , p. 58). A argumentação das autoras é complementada pelo fato de que o modelo cognitivo da écfrase deve ser o de mídia qualificada de uma performance dinâmica, e não de um artefato mimético estático.

Estabelecida em contexto histórico de florescimento das habilidades retóricas próprias ao período helenístico e à cultura romana, a écfrase é um exemplo de exercício retórico em que o enunciador e a audiência devem estar envolvidos em uma performance interativa nos niveis corporal e mental (FÜHRER; BANASZKIEWICZ, 2014, p. 48). Isso só acontece, porém, quando as intenções do autor conseguem antecipar as imagens mentais, o conhecimento, os códigos e as emoções a que o leitor está predisposto. Conforme explicam Führer e Banaszkiewicz (2014, p. 59), "através da energeia, i.e., um tipo específico de clareza, o enunciador instiga/provoca a enargeia, que é a capacidade performativa da audiência de imaginar", o que irá "provocar efeitos emocionais conectados a determinadas imagens mentais influenciadas por uma determinada cultura". A base da écfrase na Antiguidade é o poder e a ação da linguagem, que se dão quando a imaginação do locutor e de seu ouvinte na audiência se envolvem em uma interatividade performativa dinâmica e cooperativa. Aquilo que é ouvido acaba por se revelar aos "olhos da mente". Para entender como uma mídia qualificada "provoca uma visão" e/ou "evoca imagens mentais" é preciso, portanto, considerar a enargeia, ou "enargia"3.

João Adolfo Hansen (2006) reforça a importância da enargia no recurso retórico e retoma as definições de Teão, Pseudo-Hermógenes e Aristóteles, entre outros, para lembrar que, em uma écfrase com enargia, o narrador coloca o objeto narrado à frente do olho do leitor com uma vivacidade que o faz "entrar pelos ouvidos". Anne Sheppard (2014), por sua vez, usa a palavra "vivacidade"

3 A tradução "enargia" foi adotada para o termo enargeia (ou enárgeia), conforme sugerido por Melina Rodolpho (2012, p. 21) em Écfrase e evidência nas letras latinas: doutrina e práxis. 
para designar enargia em seu recente trabalho sobre a imaginação estética da Antiguidade. Já Webb (2007) explica que o termo é, de fato, muitas vezes, traduzido como "vivacidade". No entanto, pode ser usado também para designar a percepção clara e direta de algo, uma vez que os gregos não distinguiam o "ver" por meio da imaginação do "ver" com os próprios olhos (WEBB, 2007, p. 16), fazendo o ausente se tornar presente.

Pseudo-Hermógenes indica a écfrase como parte de exercícios retóricos narrativos. A classificação de Téon refere-se tanto a objetos quanto a ações, pois, para ele, a écfrase atende a descrição e a narração. Nicolau, por sua vez, sugere a inserção do adjetivo "vívido" (vividez, vivacidade), chamando a atenção para a importância da enargia, na definição de écfrase. Führer e Banaszkiewicz (2014, p. 54-58) argumentam que é exatamente esse aspecto particular que a distingue da diegese. Como a écfrase e a enargia são detectadas através tanto de análise linguística quanto de uma investigação do contexto intra e extratextual, é necessário perceber seu enquadramento narrativo e aquilo que extrapola o que seria aparentemente uma descrição (FÜHRER; BANASZKIEWICZ, 2014, p. 70). Portanto, na Antiguidade, a écfrase era entendida como um exercício retórico que envolvia tanto descrição quanto narração, com o objetivo de induzir sentimentos e pensamentos vívidos por meio da enargia, tornando o ouvinte um espectador.

Führer e Banaszkiewicz (2014, p. 48-50) argumentam que a libertação da écfrase de seu enquadramento referencial e de sua limitação ao objeto possibilita um modelo geral de écfrase como um convite verbal para imaginar e entrar em uma cena evocada pelo agente focalizador. Intrinsicamente ligada à habilidade retórica de suscitar uma imagem imediata na mente da audiência através da enargia, a écfrase propositadamente provoca uma resposta emocional. Além de levada para fora dos domínios estabelecidos pela dicotomia narração-descrição, a discussão do conceito de écfrase deve considerar os efeitos causados no receptor. As autoras sugerem que o foco no termo clássico enargia é uma das soluções possiveis para muitos dos problemas encontrados em discussões contemporâneas sobre a écfrase.

Webb (2009, p. 61) relaciona uma surpreendente variedade de fontes inspiradoras da écfrase na Antiguidade - batalhas, crocodilos, cidades, edificios, pessoas e festivais -, que eram classificadas em: pessoas (prosopa), lugares (topoi), tempo (chronoi), eventos (pragmata) e ainda plantas e animais. A autora explica que, apesar de não existir uma subdivisão dedicada somente a obras de arte, pinturas e estátuas também inspiravam écfrases (WEBB, 2012, p. 11). No entanto, estudos e traduções dos séculos XVIII e XIX favoreceram as obras de arte como objetos de écfrase, o que resultou na redefinição do termo na contemporaneidade.

$\mathrm{Na}$ tentativa de trazer um momento passado e/ou uma cena ausente mentalmente para o "aqui e agora" na Antiguidade, a écfrase se ocupava do conceito de referencialidade - mimesis -, tradicionalmente aplicado às mídias qualificadas, como literatura, pintura, escultura, artes visuais, arquitetura, dança, performance e seus equivalentes no mundo real. Esse ato comunicativo de performance retórica interativa, porém, se perdeu quando a écfrase foi compreendida dentro do conceito moderno de descrição, em contraste semântico com o de narração (FÜHRER; BANASZKIEWICZ, 2014, p. 53). Em suma, a partir do sentido moderno difundido no século XX, a écfrase acontece quando, em um processo mental, a evocação de uma imagem visual é desencadeada a partir de sua verbalização, 
por intermédio de um texto lido ou escutado. Por isso, o estudo da écfrase na contemporaneidade pode, e deve, extrapolar seu entendimento do século XIX, deixando de ser apenas uma modalidade de descrição e retomando a propriedade performativa desse exercício retórico, agora recurso literário.

Melina Rodolpho (2012, p. 169) explica que, "por tratar-se de uma modalidade que também aparece em outras", a noção de écfrase era controversa já na Antiguidade. Afinal, "dependendo do contexto inserido", pode exercer tanto a função global de detalhar quanto a função específica de evidenciar o objeto ao espectador (RODOLPHO, 2012, p. 169). A maioria das definições do termo écfrase propostas depois de meados do século XX não se atém somente ao potencial descritivo e reforça a qualidade representativa das obras de arte como sua única fonte inspiradora. Quando os estudos da representação verbal se tornaram uma área de interesse, Leo Spitzer (1962) trouxe o termo de volta para o discurso literário a partir de uma releitura da problemática da separação entre as artes do tempo e as artes do espaço apresentada por Gotthold Ephraim Lessing (1998) em Laocoonte ou sobre as fronteiras da pintura e da poesia. Spitzer (1962, p. 72) define a écfrase como "uma descrição poética de uma obra de arte", ou "une transposition d'art", técnica desenvolvida por Théophile Gautier (1811-1872), que reproduza por meio de palavras objetos de arte "sensualmente perceptiveis" aos moldes da tradição ut pictura poesis ${ }^{4}$. O artigo divisor de águas de Rensselaer W. Lee (1967) historia detalhadamente as inter-relações e a rivalidade entre as artes, de acordo com o entendimento na Renascença, convocando efetivamente o discurso horaciano para os estudos modernos. Ainda nos anos 1960, Murray Krieger (1998) revisitou o Laocoonte, elevando, em definitivo, o status da écfrase de gênero literário ${ }^{5}$ específico para princípio literário. A proposta de Krieger possibilitou a bem acolhida definição de James Heffernan (1993, p. 3) delineada nos anos 1990: "representação verbal de uma representação visual". Heffernan (1993) consegue, assim, abandonar as tentativas de separação entre as artes. Para o autor, a écfrase é fascinante por evocar o poder de imagens silenciosas, por ser tangivel e não impressionista, e também por observar como a "história da literatura pode ser escrita como uma história de sua permanente resposta conflituosa às artes visuais" (HEFFERNAN, 1993, p. 1-2). A capacidade de "falar sobre, por e para" (HEFFERNAN, 1993, p. 7) suas fontes de inspiração é um aspecto fascinante da écfrase.

W. J. T. Mitchell (1994, p. 151-156) toma emprestada a definição de Heffernan para, em um discurso politizado, propor três fases do que ele chama de fascinação ecfrástica: a indiferença, a esperança e o medo. Dentro da chamada "esperança ecfrástica", ele discute como o olhar (gaze) masculino do objeto feminino promove a dominação social e de gênero por meio de uma "imagem ecfrástica como o outro feminino"7 (MITCHELL, 1994, p. 168).

Também a partir da proposta de Heffernan, que exclui toda pintura não representativa, toda escultura e todo tipo de arquitetura, Clüver (1998, p. 13)

4 No original: "[ekphrasis is] the poetic description of a pictorial or sculptural work of art, which description implies, in the words of Théophile Gautier, 'une transposition d'art', the reproduction through the medium of words of sensuously perceptible objets d'art (ut pictura poesis)". Todas as traduções de citações apresentadas neste ensaio são de minha responsabilidade, salvo menção contrária.

5 Na linha de Krieger, a écfrase é aqui entendida menos como um gênero literário, e mais como um procedimento intermidiático. 6 No original: "Ekphrasis does not only speak about works of art but also to and for them".

No original: "ekphrastic image as a female other". Segundo Mitchell (1994), essa sugestão é válida a partir de uma perspectiva masculina, o que não é o caso dos produtos culturais aqui investigados. $O$ autor deixa claro que se sua investigação partisse de poemas escritos por mulheres, a conclusão poderia ter sido diferente. 
define écfrase como "a representação verbal de um texto ou textos reais ou fictícios compostos em sistemas sígnicos não verbais"8. Em recente artigo, Clüver (2017) discute a possibilidade da mídia cinema ser, ou não, incluída nos estudos sobre écfrase e reformula sua definição para "representação verbal de configurações reais ou fictícias compostas numa mídia visual não-cinética". Além de abarcar tanto as fontes de inspiração existentes quanto as imaginárias ${ }^{9}$, sua definição abrange as artes tradicionais, as pinturas não representativas, a escultura, a arquitetura e ainda as novas mídias. Saindo dos dominios do discurso interartes, a proposta de Clüver abre as portas para o estudo da écfrase em diferentes mídias, possibilitando a análise da écfrase arquitetônica, que inclui, além das edificações, os elementos arquitetônicos, as peças de design e os espaços urbanos. No entanto, mesmo com a viabilidade de aplicação de propostas mais arrojadas e abrangentes como a de Clüver, a grande maioria das análises contemporâneas (realizadas desde 2010) ainda mantém o foco no estudo de poemas, como observado no volume editado por Nancy Pedri e Laurence Petit (2013) e na tese de doutoramento de Emma Tornborg (2014), publicada em livro. E mesmo no volume recém-editado por Gabriele Rippl (2015), dos sete artigos da seção intitulada "Ekphrasis", cinco tratam de poesia e pintura.

Apesar de Simon Goldhill (2007, p. 1) afirmar que "a literatura atualmente em voga sobre écfrase não clássica [...] raramente domina adequadamente o material clássico", a proposta de Clüver retoma da Antiguidade a importância do papel da oratória e da enargia na écfrase. Entretanto, em seu mais recente artigo, Tamar Yacobi (2013) apresenta um contra-argumento a essa ênfase dada à enargia. A autora investiga poemas que aparecem impressos ao lado das obras de arte, não se fazendo, portanto, necessária a preocupação do poeta em tornar visível aquilo que está ausente do campo de visão do leitor (YACOBI, 2013, p. 15). O argumento é válido, por exemplo, no âmbito dos estudos acerca de exibições em museus e suas respectivas publicações. No entanto, a pesquisa empreendida, fundamentada em objetos literários, está em acordo com a premissa de Führer e Banaszkiewicz quanto à importância do resgate de elementos da retórica clássica pelos estudos contemporâneos da écfrase como recurso literário, bem como com a proposta de Clüver de que uma das principais caraterísticas da écfrase é exatamente a qualidade de se "fazer ver", desencadeada por imagens mentais que compõem um processo de entendimento mútuo entre escritor e leitor.

Assim como Irina Rajeswsky (2012) considera intermidialidade um termo guarda-chuva, Yacobi (1995, p. 600) também vê a écfrase como tal, uma vez que é um recurso literário que evoca a arte espacial, ao abranger "várias formas de representar o objeto visual em palavras"10. Ela afirma que "a representação do universo de uma obra torna-se a reapresentação de outra, uma mimese em segundo grau"11, e sugere que "o trânsito entre artes visuais e literatura sempre

8 A tradução da definição de 1997, "a representação verbal de um texto real ou fictício composto num sistema sígnico não verbal" (CLÜVER, 1997, p. 26), está disponibilizada em "Intermidialidade" (CLÜVER, 2008, p. 18). Na nota 8, Clüver apresenta a atualização de sua definição no plural, em acordo com sugestão de Tamar Yacobi.

9 John Hollander (1988, p. 209) cunhou o termo écfrase nocional (notional ekphrasis) para distinguir as verbalizacões de imagens imaginárias ou de obras de arte perdidas ou destruídas ao longo dos tempos daquelas écfrases factuais de imagens reais geradas por objetos existentes, segundo o autor, actual ekphrasis.

10 No original: "ekphrasis, the literary evocation of spatial art, is an umbrella term that subsumes various forms of rendering the visual object into words". Tradução inédita de Eliana L. L. Reis.

11 No original: "the one work's representation of the world then becomes the other's re-presentation, a mimesis in the second degree". Tradução inédita de Eliana L. L. Reis. 
destacou as relações alusivas entre obras em diferentes mídias (miméticas, temáticas e de citação)"12 (YACOBI, 1995, p. 600). A autora deixa os domínios dos estudos interartes e define "écfrase como uma forma de citação intermidiática: reapresentação verbal da arte visual", sendo que a arte visual "representa algum objeto de primeira ordem" (YACOBI, 2013, p. 2). Ou seja, aquilo que era "originalmente uma imagem autônoma do mundo [...] torna-se uma imagem de uma imagem, uma transferência ecfrástica, uma parte de um novo todo, uma inserção visual dentro de um enquadramento verbal" (YACOBI, 2013, p. 2, 3). É importante pontuar que as visões de Clüver e Yacobi apresentam uma diferença crucial: na mesma linha de Heffernan, a definição de Yacobi ainda se atém às artes visuais, enquanto a de Clüver abrange também a reapresentação de novas mídias. É fato, porém, que as duas propostas, a de Clüver e a de Yacobi, contribuem para que os estudos da écfrase extrapolem a tradição da investigação de poemas sobre pinturas.

No âmbito dos estudos sobre Intermidialidade, Irina Rajewsky (2012) menciona a écfrase em duas das três categorias propostas em seu modelo de categorização para o estudo de fenômenos midiáticos. Para ela, a écfrase se encaixa, por um lado, na categoria referência intermidiática, mas, por outro, pode também ser entendida como uma transposição midiática. Essa categoria, considerada "genética" (RAJEWSKY, 2012, p. 24-26), representa claramente o cruzamento de fronteiras entre diferentes mídias, ou seja, o processo resultará em uma nova obra pertencente a uma determinada mídia - tradicionalmente um poema -, mas irá se referir a outra mídia - tradicionalmente a pintura.

Com base em sugestão de diferentes teóricos em prol da ampla construção das fronteiras da écfrase "dentro, mas também parcialmente fora, dos limites de representação pelas mídias” (ELLESTRÖM, 2014, p. 32), Elleström (2014, p. 33) explica que, mesmo que alguém "não tenha intenção de extrapolar a noção de écfrase, deve-se admitir que é possível, habitual e que vale a pena teorizar além das fronteiras convencionais" do termo. Afinal, "independentemente das circunstâncias, poemas que representam pinturas são apenas uma parcela ínfima do amplo campo de representação de mídias complexas" (ELLESTRÖM, 2014, p. 33), afirma o autor. Ele sugere que a écfrase seja um caso de representação de uma mídia qualificada em outra mídia qualificada, como nos exemplos mais tradicionais - uma pintura representada por um poema - ou mais complexos -, como é o caso da écfrase musical, em que uma obra é representada por meio de linguagem musical (ELLESTRÖM, 2014, p. 32-34). Esse segundo caso é contestado por Clüver (2017) em seu mais recente artigo, pois para ele a écfrase deve necessariamente se manifestar verbalmente. Elleström (2014, p. 5) argumenta ainda que os estudos da écfrase deveriam ser fundidos aos da adaptação, em um conglomerado de pesquisa transmidiática, com o objetivo de ampliar o entendimento de noções como mídia, mediação, transmediação, representação, entre outras ${ }^{13}$.

A partir da qualidade representativa atribuída à écfrase no século XX, é importante também considerar que se trata de um ato de comunicação, em forma

12 No original: "the traffic between visual art and literature has always featured the allusive (mimetic, thematic, quotation-like) relations between works in the different media". Tradução inédita de Eliana L. L. Reis.

13 No original: "Hence, I suggest that existent areas of research such as adaptation and ekphrasis should be fused into a broad conglomerate of transmedial research based on a common understanding of notions such as medium, mediation, transmediation, and representation, and a wide range of other important notions". 
de interpretação, comentário ou suplemento. Para Hans Lund (1992, p. 32), não é possivel transformar uma obra de arte em palavras, devido à incapacidade do verbal de capturar a essência, o significado e o valor do visual no processo de recriação. Para ele, o texto pode direcionar a leitura da imagem a um significado não implícito na mensagem pictural em si. Ou seja, entendemos que a imagem e o texto oferecem duas experiências diferentes em duas mídias diferentes que se suplementam: a visão de cada autor irá adicionar, acrescentar algo à percepção do leitor. Ao evocar uma imagem ausente na mente desse receptor, a écfrase, com auxílio da enargia, provoca nele uma resposta de impacto emocional; como dito anteriormente, sua energia narrativa "faz ver" com tanta vivacidade que o leitor praticamente "escuta" o texto. Todavia, para que a écfrase seja bem-sucedida, o conhecimento prévio desse leitor e, principalmente, seu envolvimento com o texto são de suma importância.

A ideia de que o processo resulta em uma nova obra pertencente a uma determinada mídia, mas que se refere a outra mídia, reforça a écfrase mais como um procedimento de transposição midiática do que como uma referência intermidiática. No entanto, para o entendimento do papel da écfrase como procedimento de transposição midiática, não basta sua mera identificação. $\mathrm{O}$ enquadramento (framing) do trecho, os marcadores textuais de picturalida$\mathrm{de}^{14}$, as especificidades das mídias envolvidas e a participação do leitor no processo devem ser levados em conta no estudo do todo, e não somente dos trechos isolados.

Este ensaio historiou o termo "écfrase" desde a Antiguidade até sua definição e seu uso nos dias atuais, quando se desdobra em vários tipos, dentro dos estudos da intermidialidade. Uma passagem ecfrástica deve evocar na mente do leitor ou do espectador uma imagem ausente, para provocar nele uma resposta de impacto emocional. Seu aspecto performativo, aliado à sua energia narrativa, "faz ver" com tanta vivacidade que o leitor praticamente "escuta" o texto. Em suma, como fenômeno intermidiático, a écfrase pode ser entendida mais como um procedimento de transformação do que como uma referência midiática, uma vez que se refere a uma determinada mídia qualificada, mas resulta em uma nova obra - pertencente a outra mídia qualificada -, que, a partir de uma provocação verbal, irá desencadear uma resposta imaginativa visual na mente do receptor.

\section{EKPHRASIS: FROM ANCIENT RHETORICAL DEVICE TO CONTEMPORARY MEDIAL PHENONEMON}

Abstract: The great majority of Intermedial Studies categorization models take ekphrasis as a relevant phenomenon across media borders. Thus, the aim of this paper is to historicize the notion of ekphrasis in order to show how this ancient rhetorical device has been incorporated by contemporary Intermedial Studies as a medial phenomenon.

Keywords: Ekphrasis. Intermediality. Medial phenomenon.

14 Uma compilação de elementos picturais norteadores para o estudo de passagens ecfrásticas - desenvolvidos a partir da proposta de modelos negligenciados de écfrase por Tamar Yacobi e do diálogo entre os marcadores textuais de picturalidade presentes nas categorias propostas por Hans Lund, no modelo diferencial desenvolvido por Valerie Robillard e também na categorização dos níveis de saturação pictural do texto proposta por Liliane Louvel - pode ser encontrada na segunda parte do primeiro capítulo da minha tese de doutorado (cf. VIEIRA, 2016). 


\section{REFERÊNCIAS}

BAL, M. Essays in Narratology: on story-telling. Edited by David Jobling. Sonoma: Polebridge Press, 1991.

BAL, M. A Mieke Bal reader. Chicago: University of Chicago Press, 2006.

CHINN, C. Pliny Epistulae 5.6 and the Ancient Theory of Ekphrasis. Classical Philology, v. 102, n. 3, p. 265-280, 2007.

CLÜVER, C. Ekphrasis reconsidered: on verbal representations of non-verbal texts. In: LAGERROTH, U.-B.; LUND, H.; HEDLING, E. (Ed.). Interart poetics: essays on the interrelations between the arts and media. Amsterdam; Atlanta: Rodopi, 1997. p. 19-33.

CLÜVER, C. Quotation, enargeia, and the functions of ekphrasis. In: ROBILLARD, V.; JONGENEEL, E. (Ed.). Pictures into Words: theoretical and descriptive approaches to ekphrasis. Amsterdam: VU University Press, 1998. p. 35-52.

CLÜVER, C. Intermidialidade. Pós: Revista do Programa de Pós-Graduação em Artes, Belo Horizonte, v. 1, n. 2, p. 8-23, 2008.

CLÜVER, C. Ekphrasis and adaptation. In: LEITCH, T. (Ed.). The Oxford Handbook of Adaptation Studies. New York: Oxford University Press, 2017. p. 459-476.

COBLEY, E. Description in realistic discourse: the war novel. Style, v. 20, n. 3, p. 395-410, Fall 1986.

DERRIDA, J. Of Grammatology. Translation Gayatri Chakravorty Spivak. Baltimore: Johns Hopkins University Press, 1976.

ELLESTRÖM, L. Media transformation: the transfer of media characteristics among media. Houndmills: Palgrave Macmillan, 2014.

FÜHRER, H.; BANASZKIEWICZ, B. The trajectory of ancient ekphrasis. In: JEDLICKOVA, A. (Ed.). On description. Prague: Akropolis, 2014. p. 45-75.

GENETTE, G. Frontières du récit. In: GENETTE, G. Figures II. Paris: Editions du Seuil, 1969.

GENETTE, G. Discurso da narrativa. Tradução Fernando Cabral. Lisboa: Vega, 1995.

GENETTE, G. Palimpsests: literature in the second degree. Translation Channa Newman and Claude Doubinsky. Nebrasca: University of Nebraska Press, 1997. GOLDHILL, S. What is ekphrasis for? Classical Philology, n. 102, p. 1-19, 2007. HAMON, P. O que é uma descrição? Tradução Fernando Cabral Martins. In: VAN ROSSUM-GUYON, F.; HAMON, P.; SALLENAVA, D. (Org.). Categorias da narrativa. Lisboa: Vega Universidade, 1976. p. 57-76.

HANSEN, J. A. Categorias epidíticas da ekphrasis. Revista USP, São Paulo, n. 71, p. 85-105, set./nov. 2006.

HEFFERNAN, J. A. W. Museum of words: the poetics of ekphrasis from homer to ashbery. Chicago: University of Chicago Press, 1993.

HEFFERNAN, J. A. W. Ekphrasis: theory. In: RIPPL, G. (Ed.). Handbook of intermediality: literature-image-sound-music. Berlin: De Gruyter Mouton, 2015. p. 35-49. HOLLANDER, J. The poetics of ekphrasis. Word \& Image, n. 4, p. 209-219, 1988. 
KRIEGER, M. The problem of ekphrasis: image and words, space and time - and the literary work. In: ROBILLARD, V.; JONGENEEL, E. (Ed.). Pictures into words: theoretical and descriptive approaches to ekphrasis. Amsterdam: VU University Press, 1998. p. 3-20.

LEE, R. W. Ut pictura poesis: the humanistic theory of painting. Art Bulletin, v. 22, n. 4, p. 196-269, 1967.

LESSING, G. E. Laocoonte ou sobre as fronteiras da pintura e da poesia. Tradução Márcio Seligmann-Silva. São Paulo: Iluminuras, 1998 [1766].

LUND, H. Text as picture: studies in the literary transformation of pictures. Translation Kacke Götrick. Lewiston; Queenston; Lampter: The Edwin Mellen Press, 1992.

MITCHELL, W. J. T. Picture theory: essays on verbal and visual representation. Chicago: University of Chicago Press, 1994.

PEDRI, N.; PETIT, L. (Ed.). Picturing the language of images. London: Cambridge Scholars, 2013.

RAJEWSKY, I. O. Intermidialidade, intertextualidade e "remediação": uma perspectiva literária sobre intermidialidade. Tradução Thaïs Flores Nogueira Diniz e Eliana Lourenço de Lima Reis. In: DINIZ, T. F. N. (Org.). Intermidialidade e estudos inter-artes: desafios da arte contemporânea. Belo Horizonte: Fale-UFMG, 2012. v. 1, p. 15-45.

RIPPL, G. (Ed.). Handbook of Intermediality: literature-image-sound-music. Berlin: De Gruyter Mouton, 2015.

RODOLPHO, M. Écfrase e evidência nas letras latinas: doutrina e práxis. São Paulo: Humanitas, 2012. (Letras Clássicas).

SHEPPARD, A. The poetics of phantasia: imagination in ancient aesthetics. London: Bloomsbury, 2014.

SPITZER, L. "Ode on a Grecian Urn"; or, content vs. metagrammar. In: SPITZER, L.; HATCHER, A. (Ed.). Essays on English and American Literature. Princeton: Princeton University Press, 1962. p. 67-97.

THE OXFORD CLASSICAL DICTIONARY. 3. ed. Oxford: Oxford University Press, 1996.

TORNBORG, E. What pictures can make us see: poetry, intermediality, mental imagery. Malmö: Bokbox, 2014.

VIEIRA, M. de P. Dimensões da écfrase: a presença da pintura e da arquitetura em romances de artista. 2016. 215 f. Tese (Doutorado)-Universidade Federal de Minas Gerais, Belo Horizonte, 2016. Disponivel em: <http://www.bibliotecadigital.ufmg.br/dspace/handle/1843/ECAP-A7UFYL>. Acesso em: 14 fev. 2017.

WEBB, R. Accomplishing the picture: ekphrasis, mimesis and martyrdom in asterios of amaseia. In: JAMES, L. (Ed.). Art and text in byzantine culture. New York: Cambridge University Press, 2007. p. 13-32.

WEBB, R. Ekphrasis, imagination and persuasion in ancient rhetorical theory and practice. Surrey: Ashgate, 2009.

WEBB, R. Ekphrasis ancient and modern: the invention of a genre. Word \& Image: A Journal of Verbal/Visual Enquiry, v. 15, n. 1, p. 7-18, Sept. 2012. 
WOLF, W.; BERNHART, W. (Ed.). Description in literature and other media. Amsterdam; New York: Rodopi, 2007.

YACOBI, T. Pictorial models and narrative ekphrasis. Poetics Today, v. 16, n. 4, p. 599-649, 1995.

YACOBI, T. Ekphrastic double exposure and the museum book of poetry. Poetics Today, v. 34, n. 1-2, p. 1-52, Spring/Summer 2013.

Recebido em novembro de 2016. Aprovado em janeiro de 2017. 